RAD Conference Proceedings, vol. 2, pp. 308-309, 2017

www.rad-proceedings.org

\title{
THE CREATION OF THE NATIONAL COMMITTEE OF MEDICAL PHYSICS IN GUATEMALA, CENTRAL AMERICA
}

\section{Erick Hernández ${ }^{*}$, Ricardo Contreras ${ }^{1}$, Cabrera Ixquiac², Osmar Hernández³, Fredy Pérez ${ }^{4}$}

${ }^{1}$ Faculty of Engineering, Universidad de San Carlos de Guatemala (National University), National College of Engineers from Guatemala CIG, Guatemala City, Guatemala

${ }^{2}$ Escuela de Ciencias Físicas y Matemática, Universidad de San Carlos de Guatemala, Guatemala City, Guatemala 3Faculty of Medicine, Universidad de San Carlos de Guatemala, Guatemala City, Guatemala

4Directorate General of Energy from Guatemala, Guatemala City, Guatemala

\begin{abstract}
The IAEA on human health reports, No. 1, Criteria and Recommendations for Academic Training, Clinical Training and Certification in Latin America, suggests that the Medical Physicists of the region be accredited. "The accreditation is issued by a duly authorized professional entity (for example, a college or a professional society) serves as a public recognition that gives quality to the service provided". The Ministry of Energy and Mines of Guatemala, which regulates the use of ionizing radiation in Guatemala through the Directorate General of Energy, took as reference for the accreditation and practice of the profession of Medical Physics in Guatemala the report No. 1 of the IAEA. For this reason, the National College of Engineers from Guatemala (CIG), where the physicists are members, created the CIG Medical Physics Commission and this commission convened to Universidad de San Carlos de Guatemala USAC (national university), Directorate General of Energy DGE and Guatemalan Association of Physics AGF to appoint their representatives for the creation of the National Committee of Medical Physics, whose functions will be to endorse the registration of medical physicists, and deliberate regarding medical physics when required.
\end{abstract}

Key words: Directorate General of Energy, Medical Physicist, the National College of Engineers, National Committee

DOI: $10.21175 /$ RadProc.2017.62

\section{INTRODUCTION}

The medical physics profession in Guatemala began in 1995 in the area of radiotherapy at the Institute of Cancerology4. Since that date, medical physics has been in a continuous development in Guatemala; Erick Hernández, the author of the present document, started this path.

In 2002, the Directorate General of Energy announced an agreement, which recognizes the training in medical physics that the candidates that fulfilled the requirements had at that time, according to the enunciated agreement.

In Guatemala, there are no training programs in the medical physics field, so the existing medical physicists have been trained in different countries outside Guatemala, with different training programs. Thus, the academic training is not known with certainty and that is also the case with the practice that these professionals have.

This paper presents the legal foundations and the steps that led to the creation of the national medical physics committee and is expected to serve as a guide for other countries wishing to create such committee.

Theoretical framework: For the creation of the National Committee of Medical Physics in Guatemala, a rigorous analysis of the Guatemalan legislation was made, so that it had a very strong base; it presents the reasons why the Guatemalan Engineers College is the professional association that directs this Committee.

The Constitution of Guatemalan Republic, in the Article 90. PROFESSIONAL COLLEGE. The association to this college of university professionals is mandatory and will have for purposes the moral, scientific, technical and material improvement of the university professions and the control of their work of practice.

The Law 11-86: LAW FOR THE CONTROL, USE AND APPLICATION OF RADIOISOTOPES AND IONIZING RADIATIONS, Article 5. The purpose of this law is to control, supervise and regulate all activities related to the use of radioisotopes and ionizing radiation in its various fields of application in order to protect the health, property and environment of the inhabitants of the Republic. As well as state assets article 7. Competent Unit. The Direction is the

* erick.hernandez@rla.com.gt 
Ministry unit that is responsible for monitoring, supervising, controlling and establishing the minimum safety conditions to be observed in the activities indicated in Article 6 of radioisotopes and ionizing radiation.

The Directorate General of Energy DGE, belonging to the Ministry of Energy and Mines (MEM) is the institution that regulates the use of ionizing radiation in the country. The MEM issued ministerial agreement 137-2016, in which it adopts as a complementary provision to Law 11-86 the report on human health of IAEA No. 1, Criteria and recommendations for its academic training, clinical training and certification in Latin America. In this document it is recommended "In any of the above cases, it is highly recommended the certification of the competences by a panel or committee of experts duly accredited for this purpose, with a view to obtaining individual licensing for the exercise of the profession ... It is this type of certification process that needs to be promoted and supported by the competent national authorities (academic, health and regulatory)".

In Guatemala, the control of the professional practice is commissioned to professional associations; physicists and engineers in their different specialties (exception - chemical engineer and agronomist) are collegiate in the College of Engineers of Guatemala, the reason why it was identified that it is appropriate for this college to promote the national committee of physics and medical physics and that the University of San Carlos de Guatemala, the only national university, to endorse the certifications issued by the national committee, as a higher academic authority, the Directorate General of Energy as a regulatory office and the Guatemalan Association of Physics AGF (civil association), as a civil association that brings together physicists in all its branches in the country.

\section{RESULTS}

On August 15, 2016, National College of Engineers from Guatemala made official the creation of the CIG Medical Physics Commission; and within this commission was created the National Committee of Medical Physics formed by the National College of Engineers from Guatemala, San Carlos University of Guatemala, Guatemalan Association of Physics and Directorate General of Energy.

\section{CONCLUSIONS}

The creation of the Medical Physics Commission of the CIG will allow the regularization of the professions practice, to join the professionals with medical physics training, union defense, to propose legal technical standards and a place for discussion of different subjects of the specialty.

Acknowledgement: Engineer Murphy Paiz, President of Guatemalan Engineers College.

\section{REFERENCES}

1. Ministerio de Energía y Minas de Guatemala. (13/05/2016). 137-2016 Acuerdo Ministerial. (Ministry of Energetics and Mining of Guatemala. (May 13, 2016). 137-2016 Ministerial Agreement.)

2. Asamblea Nacional Constituyente. (17/11/1993). Constitución Política de la República de Guatemala. (National Constituent Assembly. (Nov. 17, 1993). The Constitution of the Republic of Guatemala.) Retrieved from: https://www.oas.org/juridico/mla/sp/gtm/sp gtm-inttext-const.pdf

Retrieved on: Jan 23, 2017

3. Gobierno de Guatemala. (10/01/1986). 11-86 Decreto Ley. (The Government of Guatemala. (Jan. 10, 1986). 11-86 Law decree.)

Retrieved from:

http://www.mem.gob.gt/wpcontent/uploads/2012/05/1.2-Ley-para-el-ControlRadioisotopos-y-Radiaciones-Dec-Ley-No.-11-86.pdf Retrieved on: Jan 23, 2017

4. E. Hernandez et al., "Medical Physics in Guatemala (Historical review)", in Proc. of the IRPA 2013, Glasgow, Scotland, 2013.

Retrieved from: http://www.irpa.net/members/P03.65.pdf

Retrieved on: Jan 20, 2017

5. Congreso de la República de Guatemala. (21/12/2001). Decreto No. 72-2001 Ley de Colegiación Profesional Obligatoria. (Congress of the Republic of Guatemala. (Dec. 21, 2001). Decree No. 72-2001 Obligatory act on Professional Associations.)

Retrieved from:

http://www.cpa.org.gt/wpcontent/uploads/2012/12/leydecolegiacionprofesional. pdf

Retrieved on: Jan.23, 2017

6. "Informes sobre salud humana del OIEA: Criterios y recomnedaciones para su formación académica, entrenamiento clínico y certificación en América Latina," Organismo Internacional de Energía Atómica, Viena, Austria, 2010. ("IAEA on human health reports: Criteria and Recommendations for Academic Training, Clinical Training and Certification in Latin America," International Atomic Energy Agency, Vienna, Austria, Rep. 1, 2010.)

Retrieved from:

http://wwwpub.iaea.org/MTCD/Publications/PDF/P1424 S web. pdf

Retrieved on: Jan. 22, 2017

7. Dirección General de Energía. (14/02/2001). No. 552001 Reglamento de seguridad y protección radiológica de la ley para el control, uso y aplicación de radioisótopos y radiaciones ionizantes. (General Directorate for Energy. (Feb. 14, 2001). No. 55-2001 Safety and radiological protection regulation by law for the control, use and application of radioizotopes and ionizing radiation.)

Retrieved from:

http://www.mem.gob.gt/wpcontent/uploads/2012/05/1.1-Reglamento-de-

Seguridad-y-Proteccion-Radiologica.pdf Retrieved on: Jan 21, 2017

8. Leyes y Reglamentos, Universidad de San Carlos de Guatemala, Ciudad Universitaria, Guatemala, 2006. (Laws and Regulations, University of San Carlos, University City, Guatemala, 2006.) 